\title{
PREVALENCE OF OCCUPATIONAL DISEASES AND PRACTICE OF SAFETY CONTROL MEASURES AMONG HEALTH WORKERS OF GENERAL HOSPITAL MINNA
}

\author{
UDC 616-057:614.2(669.1)
}

\author{
Idris M. Sheshi' ${ }^{1}$ Emmanuel B. Agbana ${ }^{2}$ \\ ${ }^{1}$ Ministry of Health, Minna, Niger State \\ ${ }^{2}$ Department of Community Medicine, College of Health Sciences, Kogi State University
}

\begin{abstract}
This study determines the prevalence of occupational diseases and safety practices among health workers of General Hospital, Minna. The study was Cross Sectional Descriptive. Stratified Sampling Technique was adopted. Semi structured questionnaire was used to collect data. Data were analyzed in frequency tables. The most common occupational disease among the respondents include: stress \& exhaustion $61.2 \%$, needle stick injury $52.8 \%$ and neck and low back pain $56.4 \%$. Fortytwo point eight percent (42.8\%) of the respondents have received at least one dose of Hepatitis B vaccine. Majority (57.2\%) have never received the vaccine. There was no association between socio-demographic characteristics and the receipt of vaccine. About $18.4 \%$ of the respondents have been exposed to fluids of HIV/AIDS patients through needle stick injury. Majority of them (60.9\%) have gone for post exposure prophylaxis against HIV. More than half of the respondents, $58.8 \%$ have been using Personal Protective Equipment (PPE). The study concludes that there is poor knowledge, attitude and high level of practice of control of occupational hazards among health workers who were examined. Health education and training of health workers on occupational hazards and their control should be enhanced.
\end{abstract}

Key words: occupational illness, physiological mechanism, occupational safety, safety measure, health education

JEL Classification: I10, I18, J24

Received June 13, 2018 / Accepted November 9, 2018

Corresponding author: Emmanuel Busayo Agbana

Kogi State University, Anyigba, Department of Community Medicine, College of Health Sciences, Nigeria

E-mail: modupenafiu@gmail.com 


\section{INTRODUCTION}

Health care workers have direct or indirect contact with a patient. ${ }^{1}$ These include physicians, nurses and allied health professionals working within healthcare system either in the community, in hospital or in clinic .

Occupational illness is a condition that results from occupational exposure to a physical, chemical or biological agent to such an extent that normal physiological mechanism is affected and the health of the workers is impaired. ${ }^{2}$

Healthcare workers can be categorized into those that deal with patients directly or with their secretions and blood, and those whose work in the office. Those that deal directly with patients are more at risk of occupational hazard. Health care workers deal with a wide range of activities that pose threat to their health. ${ }^{3}$ The risk is usually grouped according to the type of physical, chemical, biological, ergonomic and psychosocial hazards. ${ }^{3}$ The most common physical hazards is ionizing radiation from $\mathrm{x}$ rays, while most common chemical hazard is from anti-cancer drugs exposure through skin contact or inhalation. Ergonomic hazards include physical work which affects joints and muscles. The psychosocial hazard is a result of a man to man interaction. ${ }^{3}$

Non-fatal occupational injuries and illnesses of healthcare workers are among the highest in all industrial sectors. ${ }^{4}$ By contrast, two of the most hazardous industries, agriculture and construction, are nowadays safer than they were a decade ago. ${ }^{4}$ Healthcare facilities around the world employ over 99 million staff who are exposed to different hazards in their workplaces. ${ }^{5}$ Healthcare workers need protection from these hazards, since their job is to take care about infected people, thus making them constantly exposed to an injury or an illness. They are expected to sacrifice their own wellbeing for the sake of their patients. ${ }^{5}$ The delivery of quality health services to the general populace begins with the planned protection of the healthcare workers. ${ }^{5}$ Unsafe working conditions contribute to workers' attrition because of the fear of getting infected. ${ }^{5}$

Occupational safety among health care workers is often neglected in low income countries in spite of the greater risk associated with occupational exposure to blood, inadequate supply of personal protective equipment and limited organizational support for safe practice. ${ }^{6}$

WHO global burden of disease from sharps injuries to healthcare workers showed that $37 \%$ of the hepatitis B among health workers was the result of occupational exposure. Less than $10 \%$ of HIV among health workers is the result of an exposure at work. ${ }^{5}$ Needle stick injuries are the cause of $95 \%$ of the HIV occupational seroconversions. ${ }^{5}$

In a study ${ }^{7}$, the prevalence of hepatitis B surface antigen among surgeons in Lagos was found to be $25.7 \%$ as compared to $15 \%$ in the control group. The frequency of antibody to the surface antigen was $22.2 \%$ among the surgeons and $4.1 \%$ in the control group. On the other hand, the frequency of antibody to the core antigen was $61.7 \%$ among surgeons as compared to $53.4 \%$ in the control group.

The study ${ }^{8}$ that aimed to determine the prevalence and the risk factors for low back pain among nurses revealed that $73.53 \%$ of nurses are in a 12 -month period of low back pain. Low back pain was more prevalent among women $(68 \%)$ than man $(32 \%)$.

The role of health workers is to take care of patients. Occupational health services will lead to sound or healthy workforce. This study should raise the awareness of health workers to seek for health care when the situation demands or to take measure to protect them at the workplace. 
Occupational disease experiences by the healthcare workers can lead to the reluctance of the health worker to take care of the patient when they are exposed. In addition, some health workers may decide to relinquish their work and find a job in another sector simply because of Ebola virus disease or in a case of death of medical personnel in General Hospital Minna. This study should inform the policymakers to put in place safety measures in the hospital for healthcare workers.

The aim of this study is to determine prevalence of occupational diseases and practice of safety measure among health workers in General Hospital Minna.

\section{METHODOLOGY}

\subsection{Description of the study area}

General Hospital Minna is one of the secondary health facilities established in 1926. It is located along old secretariat road around David Mark square. It has a 300-bed capacity. It offers both primary and secondary healthcare services. It has 805 employees as shown below.

\begin{tabular}{lc}
\hline Professional category & Numbers \\
\hline Medical doctors & 53 \\
Nurses & 471 \\
Pharmacists & 32 \\
Laboratory scientist/technician & 64 \\
Dentists & 10 \\
Radiographers & 6 \\
Medical records & 60 \\
Sanitation workers & 26 \\
Security & 31 \\
Drivers & 7 \\
Accountant & 28 \\
Mortuary attendants & 2 \\
Administrative staff & 3 \\
\hline Total & 805 \\
\hline
\end{tabular}

\subsection{Advocacy}

A letter of introduction was obtained from the Ministry of Health, Niger state and presented to the Head of Hospital Services. The letter requested for permission to carry out the research. It indicated the purpose and the benefit of the research.

\subsection{Study population}

The study population included all permanent staff working for at least 6 months.

\subsection{Inclusion criteria}

The study includes all health workers of the general hospital Minna that have direct contact with patients, blood and secretions. 


\subsection{Exclusion criteria}

The following were excluded from the study:

1. Respondents acutely or chronically ill

2. Respondents who were temporary or contract staff

3. Respondents who were less than 6 months in the service

4. Respondents who travelled during the period of the research

5. Administrative staff

\subsection{Study design}

The study was Cross Sectional Descriptive.

\subsection{Sample size}

The minimum sample size for the study was determined using the Fischer's formula ${ }^{9}$ for population less than 10,000:

$\mathrm{n}=\underline{\mathrm{z}^{2} \mathrm{pq}}$

$\mathrm{n}=$ minimum sample size when population $>10,000$

$\mathrm{Z}=$ Standard normal deviate corresponding to $95 \% \mathrm{CI}$ given as 1.96

$\mathrm{p}=63.8 \% \%$ proportion of those who always use Personal Protective Equipment. ${ }^{10}$

$\mathrm{q}=1-\mathrm{p}$ (proportion of those who refused to always use Personal Protective Equipment.

$\mathrm{d}=$ degree of accuracy

$\mathrm{n}=(1.96)^{2} \times 0.638 \times 0.362$

$=355$

$$
(0.05)^{2}
$$

Since the population of the health workers of General hospital Minna is < 10,000

$\mathrm{nf}=\underline{\mathrm{n}}$

$$
1+\underline{\mathrm{n}}
$$

$\mathrm{N}$

Where $\mathrm{nf}$ is the desired sample size when population is less than 10,000 .

$\mathrm{n}=$ desired sample size when the population is greater than 10,000

$\mathrm{N}=$ Population of health workers of General Hospital Minna (target population)

$=\underline{355}$

$1+\underline{355}$

774

$=243$

For non-response $=\frac{243}{0.9}$

$=270$

For this study 300 sample size will be used 


\subsection{Sampling technique}

All the professional healthcare workers were chosen except those not working directly with patients. Stratified Sampling Technique was adopted for allocating questionnaires as shown

Number of staff in each profession $x 300$

Total number of staff

\begin{tabular}{lcc}
\hline Professionals & Number & No. of allocated questionaire \\
\hline Clinicians & 63 & 21 \\
Nurses & 471 & 190 \\
Pharmacists & 32 & 13 \\
Laboratory Scientists/Technicians & 64 & 26 \\
Physiotherapy & 2 & \\
Radiographers & 6 & 1 \\
Sanitation workers & 26 & 8 \\
Mortuary attendants & 2 & 1 \\
Drivers & 7 & 3 \\
Security & 31 & 11 \\
Medical records & 60 & 23 \\
Total & 774 & 300 \\
\hline
\end{tabular}

In each profession, sampling frame was formed. This was divided by the allocated sample size to determine the sampling interval. The first respondent was chosen through random sampling technique by balloting. Subsequent respondent was obtained by adding the sampling interval continuously until the final respondent was chosen. The respondents were administered with semi-structured self-administered and interviewer administered questionnaire.

\subsection{Data collection}

Data were collected by the researcher and edited manually to detect the omission and to ensure uniform coding after they were entered into the computer. Data analysis was done using SPSS. Data were presented as frequency tables, charts and figures.

\subsection{Ethical issue}

1. Ethical approval was obtained from the General Hospital Ethical Committee, Niger State.

2. Informed written consent was obtained from the subject before conducting the research. 


\section{RESULT AND DISCUSSION}

\subsection{Data presentation and analysis}

About 300 questionnaires were distributed and 250 were returned and analyzed.

Table 1A Respondents' socio demographic characteristics

\begin{tabular}{lr}
\hline Variables & Frequency $(\%)$ \\
\hline Age groups & \\
$\leq 27$ & $34(13.6)$ \\
$28-37$ & $70(28.0)$ \\
$38-47$ & $84(33.6)$ \\
$48-57$ & $60(24.0)$ \\
$\geq 58$ & $2(0.8)$ \\
Gender & \\
Male & $81(32.4)$ \\
Female & $169(67.6)$ \\
Marital status & \\
Single & $55(22.0)$ \\
Married & $189(75.6)$ \\
Widowed & $6(2.4)$ \\
Family type & \\
Monogamy & $161(64.4)$ \\
Polygamy & $89(35.6)$ \\
Number of dependants & \\
$\leq 4$ & $181(72.4)$ \\
$\geq 5$ & $69(27.6)$ \\
Tribe & \\
Nupe & $104(41.6)$ \\
Gwari & $107(42.8)$ \\
Hausa & $20(8.0)$ \\
Others & $19(7.6)$ \\
\hline
\end{tabular}

Majority of the respondents $(33.6 \%)$ are within the age group 38-47 years. This is followed by $28-37$ years $(28 \%)$ The smallest number of respondents was in the age group over 58 years $(0.8 \%)$. The majority of the respondents were female, $67.6 \%$ while the male constituted $32.4 \%$. More than a half of the respondents $(75.6 \%)$ were married, the least were widowed $2.4 \%$.

More than half of the respondents $(53.2 \%)$ had completed tertiary education. This was followed by postgraduate level $(39.6 \%)$. More than half of the respondents were nurses, $58.8 \%$. This was followed by laboratory workers $26.0 \%$. The smallest number of respondents was other workers, $2.4 \%$.

Less than half of the respondents had clinic as their point of service. This was followed by wards $36.8 \%$. The majority of the respondents $(54.4 \%)$ were exposed to hazards for more than 8 hours. This is followed by $7-8$ hours $(37.2 \%)$ The least was $1.2 \%$ in $3-4$ hours 
Table 1B Socio demographic characteristics of the respondents

\begin{tabular}{lr}
\hline Variables & Frequency $(\%)$ \\
\hline Educational level & \\
No formal education & $1(0.4)$ \\
Primary & $3(1.2)$ \\
Secondary & $14(5.6)$ \\
Tertiary & $133(53.2)$ \\
Postgraduate & $99(39.6)$ \\
Religion & \\
Islam & $143(57.2)$ \\
Christianity & $107(42.8)$ \\
Occupation & \\
Clinician & $24(9.6)$ \\
Pharmacist & $8(3.2)$ \\
Nurse & $147(58.8)$ \\
Laboratory & $65(26.0)$ \\
Others & $6(2.4)$ \\
Point of service & \\
Clinic & $112(44.8)$ \\
Wards & $92(36.8)$ \\
Laboratory & $38(15.2)$ \\
Pharmacy & $7(2.8)$ \\
Others & $1(0.4)$ \\
Daily average hours of exposure & \\
$3-4$ & $3(1.2)$ \\
$5-6$ & $18(7.2)$ \\
$7-8$ & $93(37.2)$ \\
$>8$ & $136(54.4)$ \\
\hline
\end{tabular}

Table 2 Prevalence of occupational diseases among the respondents

\begin{tabular}{lc}
\hline Which problem have you experienced since you started your work? & Frequency $(\%)$ \\
\hline Needle Stick Injury & $132(52.8)$ \\
Latex Allergy & $30(12.0)$ \\
Back Injury & $67(26.8)$ \\
Workplace Violence & $65(26.0)$ \\
Toxic Chemical Exposure & $23(9.2)$ \\
Muscular disorders & $43(17.2)$ \\
Neck and Back pain & $141(56.4)$ \\
Exposure to Radiation & $15(6.0)$ \\
Infection From Patients & $56(22.4)$ \\
Assaults From Patients & $72(28.8)$ \\
Skin Irritation & $38(15.2)$ \\
Stress and Exhaustion & $153(61.2)$ \\
Accident & $30(12.0)$ \\
Eye Irritation & $27(10.8)$ \\
HIV/AIDS & $11(4.4)$ \\
Hepatitis & $18(7.2)$ \\
Malaria & $90(36.0)$ \\
Others & $4(1.6)$ \\
\hline
\end{tabular}




\section{Multiple Response}

The major occupational diseases among the respondents include the following; stress and exhaustion $61.2 \%$, neck and back pain $56.4 \%$, needle stick injury $52.8 \%$. Communicable diseases have the least prevalence, Hepatitis $7.2 \%$ and HIV $4.4 \%$.

Table 3 Respondents' treatment of occupational disease

\begin{tabular}{lr}
\hline What kind of treatment did you have? & Frequency (\%) \\
\hline No treatment & $5(2)$ \\
Went to chemist to buy drug & $11(4.4)$ \\
Medical professionals for treatment & $188(75.2)$ \\
Self-medication & $44(17.6)$ \\
Traditional medicine & $2(0.8)$ \\
\hline
\end{tabular}

Majority of the respondents $(75.2 \%)$ claimed they asked for a help of medical professional for treatment, followed by $17.6 \%$ relied on self-medication. Only about $0.8 \%$ of the respondents went to a traditional medicine healer.

Table 4 Association between professional lineage \& prevalence of occupational disease

\begin{tabular}{|c|c|c|c|c|c|c|c|}
\hline \multirow{2}{*}{$\begin{array}{l}\text { Professional } \\
\text { lineage }\end{array}$} & \multicolumn{2}{|c|}{ Needle Prick injury } & \multicolumn{2}{|c|}{ Neck and Back Pain } & \multicolumn{2}{|c|}{ HIV } & Hepatitis \\
\hline & Yes (\%) & No (\%) & Yes (\%) & No (\%) & Yes (\%) & No $(\%)$ & Yes (\%) No (\%) \\
\hline Clinical & $11(45.8)$ & $13(54.2)$ & $16(66.7)$ & $8(33.3)$ & $0(0.0)$ & $24(100.0)$ & $0(0.0) \quad 24(100.0)$ \\
\hline Phar & $3(3$ & & $8(100.0)$ & $0 \quad(0.0)$ & & $8(100$ & $0(0.0) \quad 8(100.0)$ \\
\hline Nursi & $94(6$ & $53(3$ & $83(56$ & $64(43.5)$ & 10( & $137(93.2)$ & $14(9.5) 133(90.5)$ \\
\hline Labor & $23(35.4)$ & 42( & $83(56.5)$ & $33(51$ & & $64(9$ & $4(6.2) \quad 61(93.8)$ \\
\hline Others & $1(16.7)$ & $5(83.3)$ & $3(50.0)$ & $3(50.0)$ & $0(0.0)$ & $6(100.0)$ & $0(0.0) \quad 6(100.0)$ \\
\hline p-value & \multicolumn{2}{|c|}{0.001} & \multicolumn{2}{|c|}{0.062} & \multicolumn{3}{|r|}{0.374} \\
\hline
\end{tabular}

Among the respondents who developed needle stick injury, nursing has the highest rate (63.9\%), followed by clinicians $-45.8 \%$. Others include pharmacy $(37.5 \%)$, laboratory staff (35.4\%). There was statistical significant association between professional lineage and development of needle stick injury, $\mathrm{P}=0.001$

Among the respondents who developed neck and back pain, pharmacy has the highest rate $(100 \%)$ followed by clinicians $-66.7 \%$. Others include nursing and laboratory staff $56.5 \%$. There was statistical significant association between the professional lineage and development of neck and back pain, $\mathrm{P}=0.062$.

Table 5 Respondents' receipt of hepatitis B vaccine

\begin{tabular}{lc}
\hline $\begin{array}{l}\text { Have you ever received Hepatitis B } \\
\text { vaccines during your work? }\end{array}$ & Frequency (\%) \\
\hline Yes & $107(42.8)$ \\
No & $143(57.2)$ \\
\hline
\end{tabular}


Majority of the respondents $(57.2 \%)$ have never received Hepatitis B vaccine during their work. About $42.8 \%$ of the respondents had received the vaccine.

Table 6 Respondents' reason for non-receipt of the vaccine

\begin{tabular}{lc}
\hline If 'No' to the above. Why? & Frequency (\%) $\mathrm{n}=143$ \\
\hline I don't want/ no Need & $44(30.8)$ \\
Thinking of cost & $21(14.7)$ \\
No enlightenment & $11(7.7)$ \\
No opportunity & $15(10.5)$ \\
No reason & $20(13.9)$ \\
Not available & $23(16.0)$ \\
Others & $19(13.3)$ \\
\hline
\end{tabular}

Among the respondents that had never received the Hepatitis B vaccines, $30.8 \%$ of them claimed that there was no need for the vaccine. About $16 \%$ of the respondents said it was due to unavailability. The smallest number of the respondents $(7.7 \%)$ said there was no enlightenment about the need to receive the vaccine.

Table 7A Association between socio demographic characteristics $\&$ receipt of hepatitis $B$ vaccine

\begin{tabular}{|c|c|c|c|c|}
\hline \multirow[t]{3}{*}{ Variable } & \multicolumn{2}{|c|}{ Receipt of hepatitis B vaccine } & \multirow{3}{*}{$\chi^{2}$} & \multirow{3}{*}{$\mathrm{P}$} \\
\hline & Yes $(\%)$ & No $(\%)$ & & \\
\hline & $\mathrm{N}=107$ & $\mathrm{~N}=143$ & & \\
\hline \multicolumn{5}{|l|}{ Age Groups } \\
\hline$\leq 27$ & $12(35.3)$ & $22(64.7)$ & & \\
\hline $28-37$ & $26(37.1)$ & $44(62.9)$ & & \\
\hline $38-47$ & $38(45.2)$ & $46(54.8)$ & & \\
\hline $48-57$ & $30(50.0)$ & $30(50.0)$ & & \\
\hline$\geq 58$ & $1(50.0)$ & $1(50.0)$ & 3.214 & 0.523 \\
\hline \multicolumn{5}{|l|}{ Gender } \\
\hline Male & $39(48.1)$ & $42(51.9)$ & & \\
\hline Female & $68(40.2)$ & $101(59.8)$ & 1.400 & 0.237 \\
\hline \multicolumn{5}{|l|}{ Marital Status } \\
\hline Single & $23(41.8)$ & $32(58.2)$ & & \\
\hline Married & $79(41.8)$ & $110(58.2)$ & & \\
\hline Widowed & $5(83.3)$ & $1(16.7)$ & 4.126 & 0.127 \\
\hline \multicolumn{5}{|l|}{ Family Type } \\
\hline Monogamy & $74(46.0)$ & $87(54.0)$ & & \\
\hline Polygamy & $33(37.1)$ & $56(62.9)$ & 1.848 & 0.174 \\
\hline \multicolumn{5}{|l|}{ Level of Education } \\
\hline Uneducated & $\begin{array}{ll}0 & (0.0)\end{array}$ & $1(100.0)$ & & \\
\hline Primary & $2(66.7)$ & $1 \quad(33.3)$ & & \\
\hline Secondary & $3(21.4)$ & 11 (78.6) & & \\
\hline Tertiary & $61(45.9)$ & $72 \quad(54.1)$ & & \\
\hline Post graduate & $41(41.4)$ & $58 \quad(58.6)$ & 4.646 & 0.326 \\
\hline
\end{tabular}


Among the respondents who had received hepatitis B vaccine, male constitute $48.1 \%$ and female $40.2 \%$. There was no statistically significant association between gender and the receipt of hepatitis $\mathrm{B}$ vaccine, $\mathrm{P}=0.237$.

Among the respondents who had received hepatitis B vaccine, majority had only primary certificate $66.7 \%$. There is no significant association between the level of education and the receipt of hepatitis $\mathrm{B}$ vaccine, $\mathrm{P}=0$.

Table 7B Association between socio demographic characteristic and the receipt of hepatitis $B$ vaccine

\begin{tabular}{|c|c|c|c|c|}
\hline \multirow[t]{3}{*}{ Variable } & \multicolumn{2}{|c|}{ Receipt of hepatitis B vaccine } & \multirow{3}{*}{$\chi^{2}$} & \multirow{3}{*}{$\mathrm{P}$} \\
\hline & Yes $(\%)$ & No $(\%)$ & & \\
\hline & $\mathrm{N}=107$ & $\mathrm{~N}=143$ & & \\
\hline \multicolumn{5}{|c|}{ Professional league } \\
\hline Clinical & $15(62.5)$ & $9 \quad(37.5)$ & & \\
\hline Pharmacy & $3(37.5)$ & $5 \quad(62.5)$ & & \\
\hline Nursing & $64(43.5)$ & $83 \quad(56.5)$ & & \\
\hline Laboratory & $24(36.9)$ & $41 \quad(63.1)$ & & \\
\hline Others & $1(16.7)$ & $5(83.3)$ & 6.520 & 0.164 \\
\hline \multicolumn{5}{|l|}{ Point of service } \\
\hline Clinic & $50(44.6)$ & $62(55.4)$ & & \\
\hline Wards & $42(45.7)$ & $50 \quad(54.3)$ & & \\
\hline $\mathrm{Lab}$ & $13(34.2)$ & $25(65.8)$ & & \\
\hline Pharmacy & $2(28.6)$ & $5(71.4)$ & & \\
\hline Others & $0 \quad(0.0)$ & $1(100.0)$ & 2.933 & 0.569 \\
\hline
\end{tabular}

Majority of the respondents who received hepatitis $\mathrm{B}$ vaccine are the clinicians $(62.5 \%)$ followed by nursing $(43.5 \%)$. The majority who refused to receive the vaccine are laboratory staff $(63.1 \%)$ followed by pharmacy $(62.5 \%)$. There is no statistical association between professional lineage and the receipt of hepatitis $\mathrm{B}$ vaccine, $\mathrm{P}=0.164$

Table 8 Respondents' Exposure to Blood/Fluids of AIDS Patients

\begin{tabular}{lr}
\hline $\begin{array}{l}\text { Exposure to blood or fluid of an AIDS } \\
\text { patients through Needle Stick Injury }\end{array}$ & Frequency (\%) \\
\hline Yes & $46(18.4)$ \\
No & $204(81.6)$ \\
\hline
\end{tabular}

Only $18.4 \%$ of the respondents claimed they had been exposed to fluids of AIDS patients, while the majority of them $(81.6 \%)$ said they had not been exposed. 
Table 9A Association between socio demographic characteristics \& exposure to blood/fluids of AIDS patient

\begin{tabular}{|c|c|c|c|c|}
\hline \multirow[t]{2}{*}{ Variable } & \multicolumn{2}{|c|}{ Exposure to Blood/Fluids of AIDs Patient } & \multirow[b]{2}{*}{$\chi^{2}$} & \multirow[b]{2}{*}{$\mathrm{P}$} \\
\hline & Yes $(\%)$ & No $(\%)$ & & \\
\hline \multicolumn{5}{|l|}{ Age Groups } \\
\hline$\leq 27$ & $6(17.6)$ & $28 \quad(82.4)$ & & \\
\hline $28-37$ & $10(14.3)$ & $60 \quad(85.7)$ & & \\
\hline $38-47$ & $14(16.7)$ & $70 \quad(83.3)$ & & \\
\hline $48-57$ & $15(25.0)$ & $45 \quad(75.0)$ & & \\
\hline$\geq 58$ & $1(50.0)$ & $1(50.0)$ & 4.041 & 0.400 \\
\hline \multicolumn{5}{|l|}{ Gender } \\
\hline Male & $21(25.9)$ & $60(74.1)$ & & \\
\hline Female & $25(14.8)$ & $144 \quad(85.2)$ & 4.520 & 0.033 \\
\hline \multicolumn{5}{|l|}{ Marital Status } \\
\hline Single & $8(14.5)$ & $47 \quad(85.5)$ & & \\
\hline Married & 37 (19.6) & 152 (80.4) & & \\
\hline Widowed & $1(16.7)$ & $5(83.3)$ & 0.731 & 0.694 \\
\hline \multicolumn{5}{|l|}{ Family type } \\
\hline Monogamy & $32(19.9)$ & $129(80.1)$ & & \\
\hline Polygamy & $14(15.7)$ & $75 \quad(84.3)$ & 0.656 & 0.418 \\
\hline \multicolumn{5}{|c|}{ Level of Education } \\
\hline Uneducated & $0 \quad(0.0)$ & $1(100.0)$ & & \\
\hline Primary & $1(33.3)$ & $2(66.7)$ & & \\
\hline Secondary & $3(21.4)$ & 11 (78.6) & & \\
\hline Tertiary & $25(18.8)$ & $108 \quad(81.2)$ & & \\
\hline Post graduate & $17(17.2)$ & $82 \quad(82.8)$ & 0.870 & 0.929 \\
\hline
\end{tabular}

Among the respondents who had been exposed to fluids of patients with AIDS/HIV, the highest percentage was males. There was a statistical significant association between the gender and exposure to fluids of AIDS/HIV patients, $\mathbf{P}=\mathbf{0 . 0 3 3}$.

Table 9B Association between socio demographic characteristics and exposure to fluids/blood of AIDS patients

\begin{tabular}{|c|c|c|c|c|}
\hline \multirow[t]{2}{*}{ Variable } & \multicolumn{2}{|c|}{ Exposure to Blood/Fluids of AIDs Patient } & \multirow[b]{2}{*}{$\chi^{2}$} & \multirow[b]{2}{*}{$\mathrm{P}$} \\
\hline & Yes $(\%)$ & No $(\%)$ & & \\
\hline \multicolumn{5}{|c|}{ Professional league } \\
\hline Clinical & $4(16.7)$ & $20(83.3)$ & & \\
\hline Pharmacy & $2(25.0)$ & $6(75.0)$ & & \\
\hline Nursing & $22(15.0)$ & $125(85.0)$ & & \\
\hline Laboratory & $17(26.2)$ & $48 \quad(73.8)$ & & \\
\hline Others & $1(16.7)$ & $5(83.3)$ & 4.049 & 0.399 \\
\hline \multicolumn{5}{|l|}{ Point of service } \\
\hline Clinic & $26(23.2)$ & $86 \quad(76.8)$ & & \\
\hline Wards & $15(16.3)$ & 77 (83.7) & & \\
\hline $\mathrm{Lab}$ & $4(10.5)$ & $34(89.5)$ & & \\
\hline Pharmacy & $1(14.3)$ & $6(85.7)$ & & \\
\hline Others & $0 \quad(0.0)$ & $1(100.0)$ & 3.871 & 0.424 \\
\hline
\end{tabular}


Among the respondents who were exposed to fluids of AIDS/HIV patients, laboratory staff constitutes the majority, followed by pharmacists $(25.0 \%)$. There is no association between professional lineage and the exposure to fluids of AIDS/HIV patients, $\mathrm{P}=0.399$.

Table 10 Respondents' receipt of post exposure prophylaxis

\begin{tabular}{lc}
\hline $\begin{array}{l}\text { Did you receive post exposure } \\
\text { prophylaxis against HIV? }\end{array}$ & $\begin{array}{c}\text { Frequency }(\%) \\
\mathrm{n}=46\end{array}$ \\
\hline Yes & $28(60.9)$ \\
No & $18(39.1)$ \\
\hline
\end{tabular}

Among the respondents exposed to fluid of AIDS patients, majority of them $(60.9 \%)$ have received post exposure prophylaxis (PEP). It is only $39.1 \%$ of the respondents who claimed they had not received it.

Table 11 Respondents' reason for non-receipt of post exposure prophylaxis against HIV

\begin{tabular}{lc}
\hline If 'No' why & $\begin{array}{c}\text { Frequency }(\%) \\
\mathrm{n}=18\end{array}$ \\
\hline Not Positive & $16(89.0)$ \\
Accessibility & $1(5.5)$ \\
Others & $1(5.5)$ \\
\hline
\end{tabular}

Among the respondents who could not receive the PEP, majority of them $(89.0 \%)$ said they were not positive cases hence it was not necessary. About $5.5 \%$ of them said it was not accessible.

Table 12 Respondents' use of glove in a workplace

\begin{tabular}{lc}
\hline How often do you use gloves & Frequency $(\%)$ \\
in your workplace? & \\
\hline Always & $140(56.0)$ \\
Regularly & $80(32.0)$ \\
Occasionally & $20(8.0)$ \\
Never & $10(4.0)$ \\
\hline
\end{tabular}

Majority of the respondents always use gloves during the working period. Thirty two percent $(32 \%)$ said they used them regularly. The least of the respondents $(4.0 \%)$ never use gloves during the work.

Table 13 Respondents' use of face mask

\begin{tabular}{lc}
\hline How often do you use a face mask? & Frequency $(\%)$ \\
\hline Always & $33(13.2)$ \\
Regularly & $58(23.2)$ \\
Occasionally & $138(55.2)$ \\
Never & $21(8.4)$ \\
\hline
\end{tabular}


Less than a half of the respondents (13.2\%) always use face mask during the working period. Majority of the respondents $(55.5 \%)$ use it occasionally, and the smallest number of the respondents $(8.4 \%)$ never use it.

Table 14 Respondents' use of protective wears

\begin{tabular}{lc}
\hline How often do you use the overall? & Frequency $(\%)$ \\
\hline Always & $85(34)$ \\
Regularly & $34(13.6)$ \\
Occasionally & $106(42.4)$ \\
Never & $25(10)$ \\
\hline
\end{tabular}

Less than half of the respondents $(42.4 \%)$ use overall protective clothing occasionally. About $34.0 \%$ of the respondents use it always. The least of the respondents $(10.0 \%)$ never use it.

Table 15 Respondents' use of safety booths

\begin{tabular}{lc}
\hline How often do you use safety booths? & Frequency $(\%)$ \\
\hline Always & $42(16.8)$ \\
Regularly & $33(13.2)$ \\
Occasionally & $72(28.8)$ \\
Never & $103(41.2)$ \\
\hline
\end{tabular}

Less than half of the respondents (41.2\%) never use safety booth. Only $16.8 \%$ of the respondents use it always. About $28.8 \%$ of the respondents use it occasionally.

Table 16 Respondents' reasons for non-use of any of the personal protective wears

\begin{tabular}{lc}
\hline If "never", please state the reasons & $\begin{array}{c}\text { Frequency }(\%) \\
\mathrm{n}=103\end{array}$ \\
\hline Not necessary & $75(72.8)$ \\
Inconvenience & $7(6.8)$ \\
Often forget to use them & $52(50.5)$ \\
Lack of enforcement & $5(4.9)$ \\
Others & $11(10.7)$ \\
\hline
\end{tabular}

Among the respondents who do not use any of the PPE, majority of them (72.8\%) said it was not necessary, followed by $50.5 \%$ who said they often forgot to use them. The least of those respondents said it was due to the lack of enforcement.

Majority of females $(68.0 \%)$ received post exposure prophylaxis, unlike males. There is no significant association between gender and receipt of post exposure prophylaxis, $\mathbf{P}=\mathbf{0 . 2 0 3}$

Majority of the respondents who attained primary school and secondary school are those that received post exposure prophylaxis $(100 \%$ each). There is no significant association between the level of education and the receipt of post exposure prophylaxis, $\mathbf{P}=\mathbf{0 . 3 6 9}$

Nurses are the majority of the respondents that received post exposure prophylaxis. No significant association exists between professional lineage and receipt of $P E P, P=\mathbf{0 . 8 4 8}$. 
Table 17A Association between socio demographic characteristics $\&$ receipt of post exposure prophylaxis against HIV

\begin{tabular}{|c|c|c|c|c|}
\hline \multirow[t]{2}{*}{ Variable } & \multicolumn{2}{|c|}{ Receipt of prophylaxis } & \multirow[b]{2}{*}{$\chi^{2}$} & \multirow[b]{2}{*}{$\mathrm{P}$} \\
\hline & $\begin{array}{c}\text { Yes }(\%) \\
\mathrm{n}=28\end{array}$ & $\begin{array}{c}\text { No (\%) } \\
n=18\end{array}$ & & \\
\hline \multicolumn{5}{|l|}{ Age Groups } \\
\hline$\leq 27$ & $4(66.7)$ & $2(33.3)$ & & \\
\hline $28-37$ & $6(60.0)$ & $4(40.0)$ & & \\
\hline $38-47$ & $8(57.1)$ & $7(42.9)$ & & \\
\hline $48-57$ & $10(66.7)$ & $5(33.3)$ & & \\
\hline$\geq 58$ & $0(0.0)$ & $1(100.0)$ & 0.269 & $0.992^{y}$ \\
\hline \multicolumn{5}{|l|}{ Gender } \\
\hline Male & $11(52.4)$ & $10(47.6)$ & & \\
\hline Female & $17(68.0)$ & $7(32.0)$ & 1.622 & 0.203 \\
\hline \multicolumn{5}{|l|}{ Marital Status } \\
\hline Single & $7(87.5)$ & $1(12.5)$ & & \\
\hline Married & $20(54.1)$ & $17(45.9)$ & & \\
\hline Widowed & $1(100.0)$ & $0(0.0)$ & 1.908 & $0.385^{\mathrm{y}}$ \\
\hline \multicolumn{5}{|l|}{ Family type } \\
\hline Monogamy & $17(53.1)$ & $15(46.9)$ & & \\
\hline Polygamy & $11(78.6)$ & $3(21.4)$ & 2.648 & 0.104 \\
\hline \multicolumn{5}{|l|}{ Level of Education } \\
\hline Uneducated & $0(0.0)$ & $0(0.0)$ & & \\
\hline Primary & $0(0.0)$ & $1(100.0)$ & & \\
\hline Secondary & $0(0.0)$ & $3(100.0)$ & & \\
\hline Tertiary & $17(68.0)$ & $7(32.0)$ & & \\
\hline Post graduate & $11(64.7)$ & $6(35.3)$ & 3.149 & $0.369^{\mathrm{y}}$ \\
\hline
\end{tabular}

Table 17B Association between Socio Demographic Characteristics \& Receipt of Post Exposure Prophylaxis against HIV

\begin{tabular}{|c|c|c|c|c|}
\hline \multirow[t]{2}{*}{ Variable } & \multicolumn{2}{|c|}{ Receipt of prophylaxis } & \multirow[b]{2}{*}{$\chi^{2}$} & \multirow[b]{2}{*}{$\mathrm{P}$} \\
\hline & $\begin{array}{c}\text { Yes }(\%) \\
n=28\end{array}$ & $\begin{array}{c}\text { No (\%) } \\
n=18\end{array}$ & & \\
\hline \multicolumn{5}{|c|}{ Professional lineage } \\
\hline Clinical & $2(50.0)$ & $2(50.0)$ & & \\
\hline Pharmacy & $0(0.0)$ & $2(100.0)$ & & \\
\hline Nursing & $15(68.2)$ & $7(31.8)$ & & \\
\hline Laboratory & $10(58.8)$ & $7(41.2)$ & & \\
\hline Others & $1(100.0)$ & $0(0.0)$ & 1.375 & $0.848^{\mathrm{y}}$ \\
\hline \multicolumn{5}{|l|}{ Point of service } \\
\hline Clinic & $14(53.8)$ & $12(46.2)$ & & \\
\hline Wards & $9(60.0)$ & $6(40.0)$ & & \\
\hline Lab & $4(100.0)$ & $0(0.0)$ & & \\
\hline Pharmacy & $1(100.0)$ & $0(0.0)$ & & \\
\hline Others & $0(0.0)$ & $0(0.0)$ & 1.563 & $0.667^{y}$ \\
\hline
\end{tabular}


Table 18 Reasons for non-use of personal protective clothing

\begin{tabular}{lcccccr}
\hline Reasons/Material & $\begin{array}{c}\text { Not } \\
\text { necessary }\end{array}$ & Inconvenient & $\begin{array}{c}\text { Often } \\
\text { forget }\end{array}$ & $\begin{array}{c}\text { Lack of } \\
\text { enforcement }\end{array}$ & Others & p-value \\
\hline Gloves & $6(60.0)$ & $1(10.0)$ & $1(10.0)$ & $2(20.0)$ & $0(0.0)$ & $\mathbf{0 . 0 0 4}$ \\
Face mask & $10(47.6)$ & $0(0.0)$ & $11(52.4)$ & $0(0.0)$ & $0(0.0)$ & $<\mathbf{0 . 0 0 1}$ \\
Overall & $5(20.0)$ & $2(8.0)$ & $18(72.0)$ & $0(0.0)$ & $0(0.0)$ & $<\mathbf{0 . 0 0 1}$ \\
Safety booths & $59(57.3)$ & $1(1.0)$ & $37(35.9)$ & $0(0.0)$ & $6(5.8)$ & $<\mathbf{0 . 0 0 1}$ \\
\hline
\end{tabular}

Among the respondents who never use gloves, the major reason given was that it was not necessary to put on gloves while working $(60.0 \%)$, followed by the lack of enforcement $(20.0 \%)$. In this case, it is statistically significant, $\mathrm{P}=0.004$.

Among the respondents who never use face mask at work, majority said they often forgot to use them $52.4 \%$, followed by those who thought it was not necessary $(47.6 \%)$. It is statistically significant, $\mathrm{P}<0.001$

Among the respondent who never use overall, majority said they often forgot to use them $(72.0 \%)$, followed by those who claimed it was not necessary $(20.0 \%)$. It is statistically significant, $\mathrm{P}<0.001$.

Among the respondents who never use safety booths, majority said it was not necessary $(57.3 \%)$, followed by those who often forgot to use them (35.9\%). In this case, statistical significance is $\mathrm{P}<0.001$.

\subsection{Discussion}

The mean age of the respondents is $.39 .58 \pm 9.861$. The modal age group is $38-47$ years. This is in contrast to a study conducted in Osun State ${ }^{11}$, Nigeria which reported modal age group of 20-39 years (80.7\%) and with mean age of 33.4 \pm 7.4 years. This may be due to the fact that, at the time of the study, the Hospital Management Board (HMB) had not conducted recruitment process for long time. Therefore, the respondents are those that have been in service for a long time.

Majority of the respondents were female $-67.6 \%$. This is in consistency with a similar study carried out in Osun State ${ }^{11}$ which showed high number of respondents to be females $(55.5 \%)$. It is also consistent with a similar study ${ }^{12}$ conducted in Tanzania $71 \%$. This is because nursing profession is the most frequent among the respondents and has a large proportion of women as their workforce.

More than half of the respondents in this study are nurses $(58.8 \%)$. This is consistent with a similar study conducted in Osun State ${ }^{11}$, which showed nurses to be a majority of the respondents $(52.4 \%)$. This is also in conformity with a similar study carried out in Malaysia $^{13}$ which showed nurses to make $48.2 \%$, due to the fact that nurses constitute the majority of working force. The implication is that nurses must be involved in any Safety Committee that may be instituted in the hospital. For any occupational disease that may occur in the hospital, one or two nurses may be affected. For this reason, any planning initiative that may be carried out in the hospital considering occupational disease control and employee safety, nurses must be involved.

The common occupational disease among the respondents is stress and exhaustion $(61.2 \%)$, neck \& back pain $(56.4 \%)$ and needle prick injury $(52.8 \%)$. This is similar to a study conducted in Ondo State ${ }^{14}$ where stress $(77.7 \%)$ took the lead in terms of common occupational disease among health workers. This is similar to a study conducted in 
Uganda $^{15}$ which reported the common occupational disease to be stress $(21.5 \%)$, and needle stick injury $(21.5 \%)$. In a similar study conducted in $\mathrm{Bida}^{16}$ the following common occupational diseases reported among clinical departments include; Needle sticks injury $23.2 \%$, stress $13.2 \%$, Hepatitis B \& C $13.9 \%$, Back pain $4.2 \%$ and violence $3.2 \%$. Needle prick injury is more common among nurses in this study $(63.9 \%)$. It is statistically significant, $\mathbf{P}=\mathbf{0 . 0 0 1}$. This is in consistency with a study conducted in Ethiopia ${ }^{17}$ which shows that it is more common among nurses $(66 \%)$. However, it is contrary to the study conducted in Bida ${ }^{16}$ where needle prick injury is more common among doctors. It may be that there is a task shifting of some procedure which is usually conducted by the doctors to the nurses. So there is a lot of work to be done by reduced number of nursing staff. This increases the probability of exposing them more to needle prick injury. If they continue to be exposed to needle stick injury, their likelihood of acquiring HIV and Hepatitis is high which will not augur well for the hospital because of their role in taking care of the patients. At the end, it leads to high morbidity among the patients.

Low back pain is one of the most common occupational diseases among the healthcare workers. It is found to be more common among the pharmacist - $100 \%$. This is contrary to a study carried out in Bida $^{16}$ in which more than a half of the respondents had back pain. It is also contrary to a study conducted in south-south, Nigeria ${ }^{18}$ where the same prevalence is $33.3 \%$ each among the subcategories of the staff. It may be due to the fact that the majority of pharmacists sit down and stand up for a long time dispensing drugs without moving from one place to another, without exercising their bodies.

Less than half of the respondents $(42.8 \%)$ had received at least one dose of Hepatitis $\mathrm{B}$ vaccine, while $57.2 \%$ of the respondents had not received the vaccine at time of the study. This is in contrast to a study carried out in Osun State ${ }^{11}$ and in Jos/Yenagoa ${ }^{19}$ where $64.2 \%$ and $64.5 \%$ received hepatitis B vaccine, respectively. It is also in contrast to a study conducted in Ethiopia and India which reported $28.7 \%$ and $19.6 \%$, respectively. The value may be the proportion of the respondents who have completed the three doses of hepatitis regimen. Among the respondents who failed to receive the vaccine, the majority $(30 \%)$ said they did not want it, probably because of the fear of side effects. Some respondents may insinuate that the hepatitis B vaccine may seroconvert to a live infection if one should receive the vaccine. This is followed by unavailability $(16 \%)$, no opportunity $(10.5 \%)$ and no enlightenment $(7.7 \%)$. This is in contrast to study carried out in Ethiopia ${ }^{20}$ where the major reason for non-receipt of Hepatitis B vaccine was its unavailability $(58.2 \%)$ followed by its cost $(18.5 \%)$. The reason is that the respondents who claimed that 'they did not want it' may not even go to the immunization section to determine whether it was available or not. There is no significant association between socio demographic characteristic of the respondents and up/take of the vaccines in this study. This is in contrast to a study conducted in Jos/Yenagoa ${ }^{19}$ where occupational subcategories of the respondents are associated with uptake of the vaccine. It is also in contrast to a study conducted in Ethiopia ${ }^{20}$ where age, marital status, level of education and type of profession are statistically significant in association with the vaccine uptake.

Less than $1 / 10^{\text {th }}$ of the respondents $(18.4 \%)$ were exposed to the fluid of HIV/AIDS through needle stick injury. This is in contrast to a study conducted in Ethiopia ${ }^{17}$ and Northern Uganda ${ }^{21}$ which shows that prevalence of exposure to fluids of HIV/AIDS patient through needle stick injury was $31.5 \%$ and $27.7 \%$ respectively. Among the respondents exposed to fluids of HIV/AIDS patients, male constitute $25.9 \%$. This is in consistence with a study carried out in tertiary hospital in Nigeria ${ }^{22}$. It may be because 
males are those who carried out some procedures with high probability of exposure to fluids of HIV patients. The implication of this is that males may be more at risk of contracting HIV than females. There is statistical significant association between gender and exposure to fluids of HIV/AIDS patients, $\mathbf{P}=\mathbf{0 . 0 3 3}$.

Among the respondents that are exposed to fluids of HIV/AIDS patients, majority of the respondents $60.9 \%$ had received post exposure prophylaxis drugs against HIV. This is in contrast to a study conducted in Mbeya Tanzania ${ }^{23}$ which shows that $22.5 \%$ of the respondents who were exposed to fluids of HIV through needle stick injury received post exposure prophylaxis. In that study it was observed that females received it more than males. In this study, females also received it more than males, although it was not statistically significant, $\mathrm{P}>0.05$. Among the respondents who failed to receive it, majority said it was because they assumed to be negative $(89.0 \%)$ whereas $5.5 \%$ said it was not accessible. This is in contrast to a study carried out in Ethiopia ${ }^{17}$ which shows that majority of respondents who refused to receive the PPE, said it was due to unavailability (55.6\%).

Majority of the respondents $(58.8 \%)$ use all personal protective equipment, while $41.2 \%$ never wear all personal protective equipment. This is in contrast to a study conducted in Kampala, Uganda ${ }^{15}$ whereby about $30.4 \%$ wear all personal protective equipment, whereas $45.1 \%$ never wear all PPE. This could be due to Hospital Policy where it has being mandatory for the workers to use PPE. It is a good control practice and prevents occupational hazards. Among the respondents who never wear PPE, majority of them $(72.8 \%)$ said it was not necessary and $50.5 \%$ said they forgot to use them. This is in contrast to a study carried out in Ethiopia, ${ }^{17}$ where the majority of the respondents $(55.6 \%)$ who never use PPE said they were not available, followed by those who forgot to use them $(22.2 \%)$ and those who doubt in their preventive capacity $(22.2 \%)$. In this study, it may be because of their perception, and they will wear PPE to avoid negative health condition (Health Belief Model). These group need to be educated before they can think of using PPE. Majority of the respondents (96.0\%) wear gloves in any procedure. This is similar to a study conducted in ${ }^{24}$ where majority of the respondents $(92.0 \%)$ use gloves. The majority of those who never use gloves said it was not necessary $(60.0 \%)$ followed by the lack of enforcement $(20.0 \%)$. It is statistically significant, $\mathbf{P}=\mathbf{0 . 0 0 4}$.

Majority of the respondents $91.6 \%$ uses face mask. This is similar to a study carried out in China ${ }^{25}$, where majority of the respondents (70.0\%) use face mask. Among the respondents who never use a face mask, the majority $(52.4 \%)$ said they often forgot to wear it and $47.6 \%$ said it was not necessary. In this case, $t$ is statistically significant, $\mathbf{P}<\mathbf{0 . 0 0 1}$.

Majority of the respondents $(90 \%)$ wears overall dress and $10 \%$ of the respondents do not wear the overall dress. Among the respondents who never use overall dress, majority $(72.0 \%)$ said they often forget to use it. While $20.0 \%$ of the respondents said it was not necessary (significance is $\mathbf{P}<\mathbf{0 . 0 0 1}$ ). Majority of the respondents $(58.8 \%)$ uses safety booths while $41.2 \%$ never use safety booths. Among the respondents who that never use safety booths, majority of them $(57.3 \%)$ said it was not necessary and $35.9 \%$ said they often forgot to use it. It is statistically significant, $\mathbf{P}<\mathbf{0 . 0 0 1}$. 


\section{CONCLUSION}

The most common occupational disease among the respondents includes the following: stress exhaustion, needle stick injuries, neck and low back pain. Less than half of the respondents have received at least one dose of Hepatitis B Vaccine. "Do not want it/No need, non-availability and cost" are the main reasons for the non-receipt of the vaccine. No socio demographic characteristic is associated with the receipt of the vaccine.

Less than $1 / 10^{\text {th }}$ of the respondents were exposed to fluid from HIV/AIDS patients. Among these respondents, high number received post exposure prophylaxis (PEP). The reasons for the non-receipt of PEP are the fact they were negative and the vaccine was not accessible. There is high rate of use of personal protective equipment (PPE) among the respondents. The reason for non-use of any of the PPE is 'not necessary' and the fact is that they often forget to use them.

\section{Recommendations}

i. There should be training on safe injection procedure to guide against needle stick injury, especially among the nurses.

ii. The Hospital Management Board should increase the number of staff to reduce stress.

iii. Some staff should be allowed break during their work to exercise their body in order to reduce musculoskeletal problem, especially the pharmacists.

iv. Sensitization of some health workers against flimsy excuses since some of them refused to take some prevention and control measures.

\section{REFERENCES}

1. Rebome R, Rodriquez Guzman J, Dubka L, Watson L, Lavole M etal. Protecting the health of healthcare workers. A global perspective www.picnet-calwp-content/uploads/ICOH_occupational Healthcare-for-Healthcare-worker.pdf

2. Occupational health hazards and illness www.Labor.gov.on.ca/english/hs/topic/health_hazards.php

3. Healthcare; Risk for health care workers. European Agency for safety and Health at work http//oshaeuropa.eu

4. Workplace safety \& Health topics CDC www.cdc.gov/niosh/topics/healthcare/

5. Occupational hazards among healthcare workers www.who.int/occupational-health/topics/hc worker/en/

6. Knowledge, perception and standard precaution among health worker in Nigeria

7. Belo C. Prevalence of hepatitis B virus marker in surgeon in lagos, Nigeria. East Afr Med J. 2000;77(5):283-5

8. Sikiru L, Hanifa S. Prevalence and risk factors of low back pain among Nurses in typical nigeria hospital, Afr Healthy Sci 2010;10(1):26-30

9. Araoye M.O. Research Methodology with statistics for health and social science, mathadex publishers. 2003;(1):118-12

10. Wilson E Sadoh, Adeniran O Fawole, Ayebo E Sado, Ayo O Oladimeji, Oladapo S Sotiloye. Practice of universal precaution among health workers. J Nati Med Assoc 2006;98(5):722-726

11. Olufemi Oludare Aluko, Ayobami Emmanuel Adebayo, Titilayo Florence, Adebisi Mathew Kolawole Ewegbemi, Abiodun Tolani Abidoye, Bukola Faith Popoola: Knowledge, Attitude and Perception of Occupational hazards and Safety Practices in Nigeria Healthcare Workers, BMC Research 2016; 9:71

12. SV Manyelr, HAM Ngonyani, E Eliakimu: The status of Occupational Safety among Health Service Providers, Tanzania, Tanzania Journal of Health Research 2008; 10(3)

13. Shamsul Kamal bin Abd. Knowledge on Occupational Health and Safety among Health care workers in Penampang. A thesis submitted in partial fulfillment of the requirement for Master of Public Health, Faculty of Medicine and Health Science, University of Malaysia. 
14. BW Osungbemiro, OA Adejumi, AD Akinbodewa, AA Adelosoye. Assessment of Occupational Health Safety and Hazard among Govt Health Workers in Ondo City, Southwest, Nigeria, British Journal of Medicine and Medical Research 2016;13(8): 1-8

15. Rawlance Ndejjo, Geoffrey Musinguzi, Xraozhong Yu, Esther Buregyeya, David Musoke, Abdullahi Ali. Occupational Health Hazrds among Healthcare Workers in Kampala Uganda. Journal of Environmental and Public Health, www.hindawi.com/journals/jeph/2015/913741

16. Adam G Umar, Abdullahi Aisha. Common Occupational health hazards among Healthcare Workers in Tertiary Health Institute in Bida, North central Nigeria. International Journal of Biomedical Rsearch 2017, 8(01):01-06

17. Filmawit Aynalem Testay, Tesfa Dejenie Habtewold. Assessment of prevalence and Determinant of Occupational Expose to HIV Infection among Healthcare Workers in selective Health Institutions in Debre Town, North Shoa Zone, Amhara Region Ethiopia 2014. AIDS Research \& Treatment

18. Ofonine E Johnson, Emmanuel Edward. Prevalence and risk factors of Low Back Pain among Workers in a Health facility in South South, Nigeria. British Journal of Medicine and Research, 2016;11(8):1-8

19. D Ogoina, K Pondei, B Adetuyi, G Chima, C Isichei, S Gidado. Prevalence of Hepatitis b Vaccination among Health care Workers in Nigeria in 2011-12. Int J. Occup Environ Med 2014; 5(1):51-56

20. Mohammed Biset Ayalew, Boressa Adugna Horsa. Hepatitis B Vaccination status among Health care Workers in a Tertiary Hospital in Ethiopia. Hepatitis Research \& Treatment 2017

21. Odongkara BM, Mulongo G, Mwetwale C, Akasiima A, Muchurguzi HV, Mukasa S, Turinawe KV, Adong JO, Katanda J. Prevalence of Occupational exposure to HW among health workers in Northern Uganda. Int J. Risk Saf Med 2012, 24(2): 103-13

22. O, Onadeko, Mary O Balogun, Olarewaju O O nigbagi, Folashade O Omokhoidon. Occupational exposure, attitude to HIV Positive Patients and uptake of HIV Counselling and testing among heath care workers in a Tertiary hospital in Nigeria. Journal of Social Aspects of HIV/AIDS, 2017; Vol 14, iss 1

23. Marcelina John Mponela, Obinna Ositadimma Oleribe, Ahmed Abade, Gideon Kwesigabo. Post Exposure Prophylaxis following occupational exposure to HIV a survey of health care workers in Mbeya, Tanzania 2009-2010. PAN African Medical Journal 2015;21:32

24. Ashley Flores, D J Pevalin. Health care workers, compliance with Glove use and effect of Glove on hand hygience 2006;7(6):14-19

25. Peng Yang, Holly Seale, Raina Macintyre, Hanjan Zhang, Zhen Zhang, Yizhang, Xiaoli Wang, Xiayy Li, Xinghuo Pang, Quanyi Wang. Mask wearing and respiratory infection in healthcare workers in Bejing, China. Braz J. Infect Dis 2011;15(2)

\section{PREVALENCIJA PROFESIONALNIH OBOLJENJA I MERE ZAŠTITE ZDRAVSTVENIH RADNIKA U OPŠTOJ BOLNICI MINNA, NIGERIJA}

U radu je prikazan stepen učestalosti profesionalnih bolesti $i$ mere zaštite koje se primenjuju $u$ praksi na primeru zdravstvenih radnika Opšte bolnice u gradu Mina. Istraživanje je sprovedeno kao studija preseka, na reprezentativnom uzorku. Za prikupljanje podataka je korišćen polu-strukturirani upitnik. Podaci su analizirani u tabelama u kojima su date frekvencije. Najčešće profesionalne bolest među ispitanicima su: stres $i$ iscrpljenost $(61,2 \%)$, ubod iglom $(52,8 \%)$ i bol u vratu $i$ donjem delu leđa (56,4\%). 42,8\% ispitanika je primilo najmanje jednu doza vakcine protiv hepatitisa B. Većina (57,2\%) nikada nije primila vakcinu. Ne postoji značajna veza između socio-demografskih karakteristika i primanja vakcine. Oko $18,4 \%$ ispitanika je izloženo telesnim tečnostima pacijenata sa HIV/AIDS-om usled uboda iglom. Većina njih (60,9\%) je primila profilaksu protiv HIV-a. Više od polovine ispitanika $(58,8 \%)$ koristi ličnu zaštitnu opremu. Zaključak je da među zdravstvenim radnicima koji su učestvovali u studiji ne postoji dovoljno znanja, kao ni dovoljan nivo kontrole profesionalnih bolesti u praksi. Iz tog razloga potrebno je poboljšati zdravstveno obrazovanje i obuku zdravstvenih radnika o opasnostima na radu i mogućnostima njihove kontrole.

Ključne reči: profesionalne bolesti, psihološki mehanizam, zaštita na radu, mere zaštite, zdravstveno obrazovanje 